\title{
Free internet as an agent of community transformation
}

\author{
Jocelyn Williams \\ School of Communication, Unitec Institute of Technology, New Zealand \\ $<$ jwilliams@unitec.ac.nz > \\ Frank Sligo \\ Department of Communication and Journalism, Massey University, New Zealand \\ $<\underline{\text { F.Sligo@massey.ac.nz }}>$ \\ Catherine Wallace \\ Department of Communication and Journalism, Massey University, New Zealand \\ $<$ C.M.Wallace@massey.ac.nz >
}

\begin{abstract}
Does the internet empower communities or perpetuate the status quo? Can universal internet access resolve education, employment, and other social gaps? We report on our longitudinal assessment of low income community access to free internet in New Zealand, in terms of new internet users' (1) community belonging, (2) internet connectedness, and (3) civic engagement. Findings show internet connectedness may have only a minimal impact on community capacity due to constraints such as family transience, difficult domestic circumstances, inadequate project resourcing, and poor literacy. Internet ubiquity may not be a strategically useful social objective unless contextual limitations are recognised and addressed.
\end{abstract}

\section{Introduction}

An intriguing book title by contemporary British artist Damien Hirst is cited by John Naisbitt in High Tech/High Touch:

I Want to Spend the Rest of My Life Everywhere, with Everyone. One to One. Always. Forever. Now. (Hirst, cited in Naisbitt, 2001, p. 28)

In an era of seemingly omnipresent cell phones, text messaging, 'pxt' and new generation videophones, widespread technological convergence, and digitisation and computer-mediated communication, Hirst's bug-eyed vision of hyper-connectivity aptly expresses the communications technology zeitgeist. Naisbitt describes Hirst's title as "an almost perfect metaphor for the internet, and for how most of us feel as we stay connected through cell phones, e-mail, and modems" (Naisbitt, 2001, p. 29). He goes on to argue though that our increasing reliance on all kinds of technology is causing us to "live our lives distanced and distracted" (ibid., p. 28). As we seek to become increasingly engaged with the world via technology, we afford less time to traditional face-to -ace interactions. Naisbitt's argument typifies concern about changes in socialisation that appears related to a global proliferation of advanced communications technologies. 
Interested in investigating whether such pessimism is warranted, in 2003 we began to research community outcomes of Computers in Homes (CIH), a New Zealand scheme in which free computers and internet access are given to selected low-income, non-internet households for a very small joining fee. Our goal in this longitudinal study is to contribute to scholarly and practitioner understanding of the interface between information and communication technologies (ICTs) and 'community ${ }^{\text {, }}$, in a setting where little indepth research has occurred.

Our orientation in framing this study is somewhat critical, for while not wishing to fault the communitarian philosophy, purpose and strategic approach of this free internet scheme, we have also become aware of situational factors that can compromise its benefits. In this article we review the literature concerning community capacity and the internet, providing background on the ICT strategy of the New Zealand government, before presenting our early findings and conclusions.

\section{The Community Building Question}

Of particular interest for our study are the claims of, for example, the New Zealand government, that ICTs are an imperative in strengthening communities, and on the other hand the view that ICTs add so much pace to our lives that there is no time left for 'connections', and social fabric suffers. This observation implies that digitally-mediated forms of connection are inauthentic, or at least much less desirable than face-to-face interactions. The latter view is typical of discourse on the sceptical side of the debate, although it is vigorously disputed (Quan Haase, Wellman, Witte, \& Hampton, 2002; Wellman \& Gulia, 1999) and vulnerable to challenge on the basis that it represents a value judgement about what 'connecting' actually means.

Yet trenchant criticism comes from such as Noam Chomsky, who asserts that the internet is a tool of totalitarian ideology and the cause of social fragmentation, commenting "it'll be used as another technique for control and manipulation, and for keeping people in their roles as mindless consumers of things they don't really want" (Chomsky, Mitchell \& Schoeffel, 2002, p. 278). Others ask whether the digital divide is a cause du jour, and whether addressing it might be beneficial to groups such as business and academia more than the digitally marginalised (Luyt, 2004; Rampersad, 2004). Why not talk about a healthcare divide instead?

Shepheard (2004) and others (Green, 2001; Lasen, n.d.) point out that public anxiety about the effects of digital communications is one in a long tradition of moral panics over technological innovations. Lasen has researched mobile telephony and compared its diffusion with the introduction of landline telephony, and found similarities in public response to these ICT innovations despite the fact that they arrived a century apart:

The launch and spread of wireless phones have aroused some fears, as happened with ... landline phones. A certain amount of 'moral panic' about its effects ensues [sic] the adoption of many new technologies. Some of these fears are similar in both cases: threats to ... health, danger of addiction, the decline of traditional interactions, the loss of interest in taking part in social activities, or inconsiderate behaviour. Others are new, such as the privatisation of public space, the intrusion of work into the private sphere, or ... increased possibilities for control (p. 42).

Lasen's point is that, to a large extent, public anxiety over ICTs is a normal part of the diffusion process. Like Lasen, Lelia Green refers to "internet moral panic" (Green, 2001) as "part of the ritual cycle of panics surrounding new technologies" (citing Marshall, 1997). Hughes and Hans (2001), assessing research on the impact of the internet on family life, cite a historical study of the automobile and the telephone in the early 20th century: Fischer found "numerous accounts that parallel the current debates". In 1926, for example, a "meeting called to discuss whether modern inventions help or hurt character and health included the following questions: 'Does the telephone make men more active or more lazy?' [and] 'Does the telephone break up home life and the old practice of visiting friends?'” (1992, in Hughes \& Hans, 2001, ๆ4). 
'Diffusion of innovation' theory (Rogers, 1995) proposes five innovation characteristics (relative advantage, compatibility, complexity, trialability, and observability), with commentators such as Li (2004) noting that the diffusion model has been criticised for its pro-innovation bias. The theory predicts that a proportion of a population, possibly either risk-averse or isolated (as for example, socially or economically), remain resistant in the uptake of a technology. A degree of scepticism about the supposed benefits of a technology is expected from some - such as those who have neither a mobile phone nor the desire for one. Also, because pricing constraints dictate high costs for technologies when first launched, the less well off, the less educated, and those lacking interest, constitute a persistent "tail-end" group. Thus concern about consequences of ICT innovations, together with an access gap (such as the digital divide) are to be expected. However, even the chief architect of these principles, Everett Rogers, has commented that in the case of the internet and mobile phones, "new technologies that will have profound impacts are evolving very quickly ... with promises to intensify the already clamorous cacophony of cyber-chatter in our ever-shrinking planet" (Martinez, 2003). There is a sense of resignation here about a significant downside to the ICT revolution.

Possibly a generational factor is involved in all this anxiety and scepticism. Marc Prensky has provided a fresh metaphor for today's young - "digital natives", those who have grown up with digital technologies and comfortable with them. "Digital immigrants" are those (often teachers and parents) who must learn new ways of thinking and behaving in a digital environment, as if learning a new culture (2001, p. 1). Prensky points to a fundamental shift in both behaviours and cognitive function, with implications for teaching and learning among today's generation. Perhaps the digital immigrants express most concern about the internet's impact.

So is there a 'right' in this debate? Should the evangelists who dismiss the risks of ICTs to community life, or the unbelievers who remain unconvinced about the benefits move us more? Does it matter? We think it does matter, given the large-scale investments in a digital future by key sectors including government, business, and education. And as noted in a recent Pew Internet and American Life Project report, "technological change is inevitable, and it will result in both beneficial and harmful outcomes" (Fox, Quitney-Anderson, \& Rainie, 2005, p. 47). Continued research is needed so that social change via ICTs becomes clearer. We acknowledge some inclination towards the sceptics' arguments, noting that a recent meta-analysis of the relationship between social capital and ICTs "suggests that a degree of 'analytical scepticism' should be extended to those advocating the deployment of ICT for creating social capital" (Pigg \& Crank, 2004, p. 69).

We have argued before that a binary paradigm of access, as in "haves" and "have nots", is an unhelpful approach to the digital divide (Williams, Sligo, \& Wallace, 2004), as have others, like Eszter Hargittai, in the face of attempts to perpetuate the importance of access (Novak \& Hoffman, 1998). Hargittai (2004) argues that we should distinguish between using the internet anywhere, using it at home, and using it through a high-speed connection, since these different access criteria determine different kinds of inequality. Accessing the internet at home, for example, permits a freer approach to web surfing than is likely at one's workplace or in a public library. Therefore, through community-based research an integrated assessment of the community-building dimension of increased internet access may occur. A priority for governments and associated agencies must then be to address the complex matter of access, and to neutralise barriers and risks.

The New Zealand government is taking an assertive position regarding the role of ICTs in the nation's future. According to the government's 2004 Digital Strategy draft policy document, universal access to "the power of ICT to harness information" for universal "social and economic gain" is the vision for the immediate future (Digital Strategy: A Draft New Zealand Digital Strategy for Consultation (DS), 2004, p. 2). "Internet Everywhere"-symbolising wireless internet and its promise of universal reach-is also to become a strategic goal for New Zealand, in the sense that those 'in' the digital divide, are to be systematically extracted from it. We now will review the universal access goal within New Zealand's Digital Strategy, and reflect on it using findings from our research within three ICT-targeted communities.

\section{The Vision of Internet Ubiquity in New Zealand}


The New Zealand government launched its draft Digital Strategy mid-2004 for consultation, aiming to present a final document to Cabinet in October 2004. According to David Cunliffe, Associate Minister for Information Technology, this strategy was to guide the government's work in positioning New Zealand as "the hub of the South Pacific" (community consultation, 30 July 2004) and "a world leader at using information and technology to realise our economic, social and cultural goals" (DS, p. 2) over the next three to four years. Ideally it will bring to fruition the government's commitment to

bring the benefits of information and communications technology to all New Zealanders - to create a society where ICT empowers everyone to create, access, utilise and share information and knowledge, enabling individuals and communities to achieve their full potential (DS, Foreword).

The Strategy sets out to be holistic in its scope, addressing not just economic but also social and cultural goals. It is also intended to serve as a whole-of-government strategy, and so was developed by several central government departments, along with local government input from the organisation Local Government New Zealand, and was coordinated by the Ministry of Economic Development. Its hope is to formulate a framework that will foster so-called "smarter" uptake of ICT by government, business and communities.

An ambitious agenda includes completion of Project Probe, a provincial broadband extension project aiming to ensure that all schools and their communities can access broadband by the end of 2004 (DS, p. 95). Cunliffe admits "we can't have computers in every home tomorrow, much as we'd like to". However, within the broader ICT vision small-scale schemes intended to close New Zealand's clearly apparent digital divide (Archer, 2004) have been endorsed, including Computers in Homes (CIH). It is of interest that government-funded initiatives such as $\mathrm{CIH}$ are viewed uncritically as a means to "seize the opportunities for increased prosperity and greater social cohesion that the effective use of the tools of ICT can deliver" ( $D S$, Foreword). Implicit in such rhetoric is an assumption that social cohesion will necessarily result from universal ICT access. Findings in some studies endorse this view, while others are less positive (Jackson et al., 2004; Kraut et al, 1998; Shah, Kwak \& Holbert, 2001). The issue remains controversial.

Our study traces participant experiences in the $\mathrm{CIH}$ scheme. The CIH programme was initiated by the N.Z. 2020 Communications Trust, financially supported by the N.Z. Ministry of Education, supported by volunteers from universities, polytechnics and community groups, and provided with paid support technicians. The 2020 Communications Trust receives sponsorship from local government and business sources. A two-year pilot began in July 2000, based in schools in Cannons Creek (Porirua) and Panmure Bridge (South Auckland). Families in two rural schools in the North Island's East Coast were included in 2001, and in the same year Wellington's Newtown School was added. The variety of such applications now makes it desirable for longitudinal research into their effects, such as the current study, to be undertaken. Specifically, in each location 25 families are given recycled Pentium 75-100 computers with Windows 95, MS Works, MS Word, a package of shareware educational games, modem, internet connection and a phone line where necessary.

Worldwide, such recycling projects aim to democratise access to ICTs; studies show that children's learning can be extended into the home; literacy can be developed; and communication between home and school may be enhanced (Zardoya \& Fico, 2001). While it has been said "the success of Computers in Homes is not disputed, but the task of consolidating the programme into government policy has not yet been achieved" (Das, 2003, p. 8), we are interested in probing the lived experiences of those involved to scrutinise the 'community transformation' rationale.

The strategy of having the $\mathrm{CIH}$ initiative spearheaded by a Trust, bankrolled by the Ministry of Education, and supported by enthusiastic volunteers looks on the surface to build on the strengths of diverse groups. Yet there would appear to be the potential for systemic failure should any of these entities lose funding, enthusiasm or momentum, or should significant differences in vision or direction emerge among these disparate parties. Ultimately a holistic plan as ambitious as the NZ government's Digital Strategy requires direction and resources of a magnitude which in the NZ context can come only from government sources. However, experience has been that building community capacity depends on a systematic and coherent central (or possibly local) government plan based on investment over a sufficient period of time for results to be seen. 
The leadership role of the principal would thus appear to be critical to the success of the program through his (or her) involvement in such areas as publicising the scheme, finding ways to involve and encourage both parents and children, and offering ongoing support to families involved. Thus we, as researchers, were aware that the key leader in the CIH innovation would be the principal of each school, and in each case his or her own belief about the potential value of $\mathrm{CIH}$ would probably constitute the difference between success and failure.

\section{The Community Connection Study}

Findings from our study of internet and community in three suburbs in New Zealand's largest city, Auckland (population one million) are emerging in stages. Our study participants are new to the internet experience; are almost entirely low-income families of school-age children (selected by the schools), and they have become engaged in the research through the expanding CIH scheme which aims to get lowincome people online $e^{\mathrm{ii}}$. As our research orientation is primarily qualitative, we prioritise the internet user perspective; data has therefore been gathered principally by seeking the insights of adult family members in extended interviews.

Other elements of our snapshot of twenty-six volunteer participants at the preliminary stages (early 2004) of their internet access at home, are researcher field notes from community and other meetings, and interviews with project leaders and champions. Analysis of interview transcripts has been conducted using open coding (Strauss \& Corbin, 1998) so that themes relating to dimensions of the internet experience can emerge. The interview also incorporates survey questions permitting numerical analysis referred to later. Here, we limit our discussion to initial phase results obtained between November 2003 and April 2004.

\section{The sample group}

Parents or caregivers of young children were approached for voluntary involvement in this research. Twelve of the initial 26 came from one school community, thirteen from another, and one parent is from a third school.

\begin{tabular}{|c|c|c|}
\hline $\begin{array}{c}\text { All participants } \\
(N=26)\end{array}$ & Characteristic & Comment \\
\hline $\begin{array}{c}85 \% \\
\text { mid-20s to mid-40s }\end{array}$ & $\begin{array}{c}\text { Comparatively young } \\
\text { parents }\end{array}$ & $\begin{array}{c}\text { Reflects the primary (junior) school } \\
\text { community population from which } \\
\text { the sample is drawn }\end{array}$ \\
\hline 77\% Female, 23\% Male & Generally female & $\begin{array}{c}\text { Women caregivers tended to take } \\
\text { responsibility for the computer at } \\
\text { home }\end{array}$ \\
\hline $\begin{array}{l}50 \% \text { no formal } \\
\text { qualifications }\end{array}$ & Low educational attainment & $\begin{array}{c}\text { Low socioeconomic status of these } \\
\text { communities }\end{array}$ \\
\hline $\begin{array}{l}61 \% \text { below NZ average } \\
\text { household income }\end{array}$ & $\begin{array}{l}\text { Below average household } \\
\text { incomes }\end{array}$ & As expected in "low-decile" areas \\
\hline $\begin{array}{l}42 \% \text { Maori } \\
35 \% \text { European } \\
23 \% \text { Pasifika }^{\text {iii }}\end{array}$ & $\begin{array}{c}\text { Higher percentages of Maori } \\
\text { and Pasifika families than } \\
\text { NZ overall }\end{array}$ & $\begin{array}{c}\text { Reflects social characteristics of } \\
\text { these suburbs }\end{array}$ \\
\hline
\end{tabular}




\section{Connectivity: Three Ways}

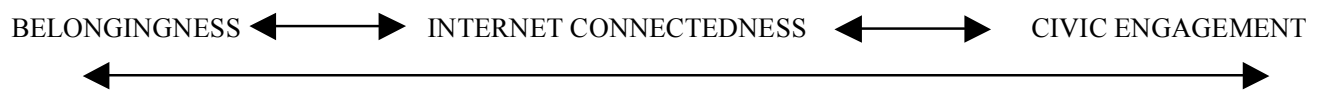

We aim to assess interactions between three dimensions of connectivity in a population of inexperienced internet users. Our three dimensions, as shown above, include (1) neighbourhood belongingness, (2) internet connectedness and (3) civic engagement. It is believed that the first and third types are linked: civic engagement, producing strengthened community, is a by-product of networks of community members who feel comfortable in their communities, as argued in the literature on "social capital". Social capital is theorised as a dimension of community function inherent in strong networks of reciprocity, and is said to be in decline in developed countries (Putnam, 1995a, 1995b, 1996, 2000; Stone, 2001; Winter, 2000a, 2000b). As explained previously, claims are asserted in favour of harnessing ICTs to rebuild community capacity.

Our remaining dimension, internet connectedness, may impact on the other two, for example, in enhancing people's sense of belonging to a community of interest, increasing neighbourhood connectivity, and providing tools to enhance civic engagement. Research on linkages between internet use and civic engagement has shown that "overall internet use was found to be positively ... related to civic engagement" (Shah, Kwak \& Holbert, 2001, p. 149), although the motive for using the internet is more important than the amount of time spent online. In particular, an informational motive is "related positively to social capital production" whereas a social-recreational motive "appears to diminish [it]" (p. 154). Yet, we wonder, might internet use undermine neighbourhood networks in favour of online networks, thus eroding local social capital? To draw conclusions on such questions and produce as rounded and robust an assessment as possible, our data on individuals' digital connectivity encompasses goals (motives) in using the internet, activities, time online, and several more. We now summarise our early findings on the three dimensions of connectivity.

\section{Neighbourhood ties}

There is an apparent disjuncture between our participants' sense of local community, and that of community leaders such as school principals involved in driving the ICT project (Williams, Sligo, \& Wallace, 2004). One principal views his role as transformative, and his mission to lift community aspirations, but the new internet users themselves display "a strong sense of local community and a pride in belonging, despite transience, travel distance and lack of property ownership" (p. 13).

Our finding arises from analysis of survey variables modelled, in part, on the Metamorphosis study in Los Angeles (Ball-Rokeach et al., n.d.), in which "belonging" was assessed on indicators such as home ownership: "increased investment into a community by owning a home is thought to increase...the likelihood of belonging" (Appendix p. 5). Yet although the large majority of our respondents rent their homes, have spent fewer than five years living in the neighbourhood, and travel a minimum of ten kilometres to work or for daily activities, we found strong indications of people very comfortable in their immediate neighbourhoods.

Two-thirds of our group felt quite proud or very proud of where they live, reported feeling positive or strongly positive about interacting with neighbours, and know a minimum of five neighbours by name and to talk to, with an average number reported of over nine. Participant 25 reflects this neighbourly feeling: "we care about each other ... you know the more I meet people here the more I stay here". Three quarters of the group agreed or strongly agreed that "I am very satisfied with the way things are going in my life these days".

On the other hand, a father regarded as a conspicuous success by his $\mathrm{CIH}$ school in acquiring the skills to find a route out of his social environment reported

I'm a born-again Christian, and I was going to suggest not at all proud, but I think because of the situation I'm in and where I' $m$ at I can see that this street here needs fixing up, needs pulling 
together ... I'm here for a reason, to clean the street up and be drug-free, because it's a predominant street for $\mathrm{P}$ and marijuana and ... this is The Bronx.

He clearly wanted to live in better circumstances, and had mixed feelings about his neighbourhood. The school principal is convinced that the $\mathrm{CIH}$ computer has been instrumental in the family's transformation. We wonder if a number of factors including the man's keen involvement in a popular charismatic church, sustained personal encouragement from the school principal, together with the arrival of the internet in the family, all contributed to the change.

\section{Internet connectedness}

Our next layer of data is provided by questions concerning internet use. After a longer period of time using the internet our participants may demonstrate more 'connectedness' as they discover more ways in which to use the technology, so we are tracking this with interest. However in the early period of being online, we might expect a range of degrees of enthusiasm due to varying levels of confidence, interest, motivation, keyboard skill, and information literacy and digital literacy. We distinguish between the last two, given that people need to be educated to achieve better understanding of the digital knowledge management environment and its broader effects, as well as the more instrumental skills of informationsearching and keyboard use. It has for example, been observed that "computers have the potential to engage youth in new types of mathematical and scientific thinking” (Resnick, Rusk, \& Cooke, 1998, p. 5), moving them beyond technical know-how to the use of computers as heuristic tools.

To obtain a benchmark measurement of internet connectedness (to support the subjective process of assessing change through anecdotal evidence, and to compact a wide range of variables into a single rating for each user) we designed an Internet Connectedness Index (ICI). Although such a rating is of limited validity outside our small sample, it produces a useful single index from 1-12, where 12 is a "high connector". iv

We used eight items covering internet behaviours and attitudes we believe to be sufficiently comprehensive, including participants' evaluation of the internet, internet dependency (how much one would miss it if it vanished), frequency online, and time spent on email. Our ICI offers an alternative method to measure internet connectedness, adding robustness to our findings through triangulation. It is also an instrument to be invoked again in Phase 2 after later participants' visits, revealing if any change has occurred.

The indices appear to underscore our interview findings. For example, a 'high connector'v participant has a Phase 1 ICI rating of 8.9, the highest index in the group. The ratings are interesting because they reinforce observations regarding which participants were already high connectors; a point expanded on below. In Phase 1 of the study our six high connectors share other characteristics, such as sociability and confidence in interviews. Analysis of survey data on "belonging" shows these individuals are interested in knowing their neighbours, and enjoy meeting and making friends with them. They are sufficiently familiar with their neighbours to know their names and say hello; and they were very unlikely to leave the neighbourhood. They were more likely to have visited or phoned someone just to talk (on the day of or the day prior to the interview), and were in the habit of phoning their families every day. These factors suggest that a predisposition to enjoying engagement with people generally might predict higher levels of internet connectedness, a possibility briefly considered but rejected in the Netville study in Toronto (Hampton \& Wellman, 2000). Of further interest is that these high connectors are also substantial consumers of media, in particular television (three to four hours per day) and radio (more than five hours per day).

Five individuals are in the low connector category (scoring an ICI of less than 5 out of 12). To this group we add a further five people who were either unable to connect to the internet by the time of their first interview despite being part of the $\mathrm{CIH}$ scheme (and for whom therefore an ICI calculation was not possible), or for whom there was missing data for various reasons. We sought patterns in the data for these ten participants but results were less conclusive. These respondents on the whole, knew fewer neighbours to talk to than the high connectors, but there was a slight tendency to report being interested in knowing neighbours, an enjoyment of meeting them and a sense that it is easy to become friends with them. They, too, mostly were unlikely to leave the neighbourhood. However although they were unlikely to have 
visited anyone on the day of, or the day prior to, the interview, they too regularly phoned their families, either weekly or daily.

Low connectors spend little time as media consumers and demonstrated one or more characteristics that may explain their low connector rating. These include less self-confidence; preoccupation with family matters such as young children or an unwell child; having a rental home viewed by potential buyers, thus facing uncertainty over where to live; adjustment to unemployment; juggling of two jobs plus children; being a grandmother and caregiver of two girls; and fearing the internet. Such pressing contextual factors may outweigh a predisposition towards social engagement generally, and erode either motivation or time available for media such as television and the internet.

The ICI data may be put to community use in reports back to schools. For example, one school featured a smaller proportion of low connectors than in the whole group. This may be suggesting conditional success in "bedding in" the $\mathrm{CIH}$ programme, in this setting, a finding of potential interest to school managers. Yet selection error may have occurred, so that simply by chance those involved in CIH in this instance were confident and motivated in working with technology. On the other hand, at a second site a high proportion of participants had low ICI scores. In other words, more participants at this site were less connected, which may signal that more support is needed for the CIH parents to enable them to more fully use their internet connection.

On the whole our respondents regarded facilitation of family and social networks as exciting and positive. Our findings reflect other studies in underlining that email continues to be "the dominant single activity on the internet"vi (Lebo, 2004, p. 13), and number 1 of "the top ten most popular internet activities"vii (p. 29). Furthermore, a "clicking cousins" phenomenon may be discerned among internet users, since email "helps extend family networks" (Horrigan \& Rainie, 2002, p. 14). The University of Southern California's Annenberg Centre for the Digital Future claims that "internet users have healthy social lives" (Lebo, 2004, p. 100) and that they spend more time in person with friends than do nonusers. It has been suggested that the communication, or relationship-building, function of the internet may be more important than the information function of ICTs in building community (Pigg \& Crank, 2004).

\section{Distanced and Distracted?}

As earlier implied, John Naisbitt's assertion about families now "living together in isolation" (2001, p. 30) "distanced and distracted" (p. 28) disputes the metaphor of the television as the new family hearth. In his view, family members are more likely to be in their own rooms, listening to their choice of music or pursuing niche media interests. Would our study find ICT fostering undesirable household changes? Our data-gathering included capturing narrative, asking questions about telephone and media use, and seeking participants' perception of observed changes in their communication behaviours.

\section{Civic engagement}

The civic engagement section of our survey included questions on organisational involvement, volunteer or community work, and whether respondents felt their behaviours had changed since their first log-on. For example, had time spent watching TV decreased, stayed the same or increased? Were they reading newspapers less, the same or more? Were there differences in the amount of time spent visiting friends and family?

On the whole, respondents were already little involved in civic activities like volunteering or community projects. Around half had some involvement in sports clubs, and fewer than half belonged to a cultural or religious group. After having the internet installed, about one-quarter reported reading the newspaper less (although some were doing so online instead) and half were watching less television. This finding is congruent with the Pew Internet and American Life Project, which reported "fully one-quarter of internet users said that surfing the internet has led to a decrease in television time" and "...fourteen percent say the internet has decreased the time spent reading newspapers". In the Pew study, these proportions are greater among internet veterans (online for three years or more). 
A small number said family time had now increased (such as through all being together at the computer), and only one person said they had less time with family. However a quarter of the group now spent less time with friends, and about one-third were talking less on the telephone with friends and family, occasionally because the single household telephone line was employed by the internet. Generally, internet use has slightly eroded civic engagement ${ }^{\text {viii }}$ in that respondents were now less actively engaged in maintaining social networks.

However, just under half also reported that the Internet had increased their feeling of connectedness with interpersonal networks, while our interviews add to the picture of civic engagement by highlighting potential community building. One example is a grandmother who anticipates the internet helping her

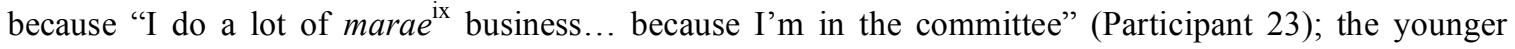
grandmother, our very high connector and focal point of family and neighbourhood, saying "it's changed my way towards other parents... I'm online now to this other lady... I took one lady home that night, and, um, we were chatting away and it was really cool learning more and more and it's like, keeping in touch more" (Participant 25). Some parents are more connected to their church communities through the internet; and at all three research sites the local school, the hub of the community, is strengthening its ties with parents by hosting the $\mathrm{CIH}$ meetings and trying to encourage email contact with the school (although little of this interaction seemed to be occurring).

\section{Challenges to Inclusion and the Next Steps}

Phase 2 of the study involves follow-up discussions with the original participants, especially a subgroup of high connectors in the early stages of their internet experiences who are highly sociable, and a second sub-group of low connectors who may struggle to become more than that because of their circumstances. We continue to meet as many of these as possible, noting whether any changes occur over time.

Various unanticipated difficulties occurred in bringing low-income families into contact with ICTs. Even an apparent strength of the CIH scheme whereby more digitally literate parents mentor the less skilled, is potentially problematic, and may be too much to ask of participant parents. One mentor reported of another parent who, "instead of listening to what he was supposed to do, he went and hooked himself up with Xtra" (the wrong Internet Service Provider, so he was billed for internet time). "So," said Participant 9, the mentor:

he's wasted a whole lot of time... I've been to his house, I've asked him, I've rung him...weekly..., asked him if everything was going all right, and then he rings me up and tells me he's got this bill for Xtra .... And I am not sure whether that was because I'm a woman and he's got a thing about women telling him what to do ....or he just....went and did what he wanted.... I mean I really don't know where he was coming from”.

Barriers also include lack of confidence, frustrating hardware and software, slow dial-up access and slow download, ${ }^{\mathrm{x}}$ inadequate telephone connections and cabling, and anxiety over perceived internet dangers. For instance, concerns exist among some interviewees, particularly older ones, that the internet represents some kind of threat to their family lives. Although Participant 24 comments

the more I use it the more I see the possibilities you know ... I'm talking about the wealth of information on it ... like booking online and all that talking through email you know ...

he is also anxious about rushing into it:

But ohh at the same time I'm wary. I just want to work my way through and have a look. I'm not going to rush into things. Because I don't really understand it.

His concern is also that

actually I try and ... make sure I don't let the Internet take over my family... I don't want to be like that - I just want to use it. .... Because I think the more I rely on it the more I want to watch it all the time, you know ... Because ... other people get too involved in it, 
and then their families suffer. ... I got to be careful, I got to be - have a balance, that's what I mean.

Similarly, a grandmother who cares for her young granddaughters and is therefore the responsible party in regard to the $\mathrm{CIH}$ computer, wants it to benefit the family but views it as somehow dangerous. Not only is it behind a closed bedroom door rather than in a family living area on the day of the interview, it is too far from the telephone jack for the internet cable to plug in, and she remarks

No, I heard all about this internet - some time I don't even really... but I got to use it for school...I want to be careful of these two you see... I think they got a fair idea of what it's about, this Internet - these two here...just want to find out more about it you see, because they know how to do it all right, even her [meaning the 7 year old] ...

We therefore signal several challenges to project leaders and government departments that look to community ICT projects as achieving "the full benefits of ICT... through the widest participation" $(D S, \mathrm{p}$. 8) because participation is the end point of a path that merely begins with putting the computer into someone's home. Thus, "It is now clear that technological tools themselves, no matter how well they are conceived and designed, are not enough" (Resnick, Rusk \& Cooke, 1998, p. 13).

A careful balance must be struck between a governmental agenda for ICT saturation aimed at social and economic transformation, and a loosely articulated intention to involve business and communities. The "transformative" power of the internet $(D S, \mathrm{p} .11)$ is reverently but uncritically invoked. Moreover our government is set to pursue a strategy devolving ICT leadership to communities themselves. In our view, this is the critical point. Perhaps considerable community benefit will accrue from internet access, but only if it is so resourced that the community itself is not left to manage with minimal support. The government's Digital Strategy relies heavily on a philosophy that the will, leadership and skill will arise from the grassroots: it is to be a devolutionary strategy. It seems to us, however, that questions need to be answered in view of research by the (US) Pew Internet and American Life Project showing that over half of Americans without internet access have no plans to log on (Rainie \& Packel, 2001).

At two of our research sites, community leaders do view themselves as digital missionaries, even though the uninitiated appear content with their lot and have not yet recognised their digital baptism as a path to salvation. Instead they view the computer quite pragmatically as another household convenience, a gadget - not necessarily investing it with powers to conjure up miracles, as some rhetoric seems to imply. If the gadget works, fine; if it does not work, well, we have other things to attend to in our lives...

Education to create understanding of the reasons why people should want internet access, or what they can do with it, is clearly lacking. The government admits it is missing too: "raising community awareness of ICT" $(D S$, p. 59) is, reassuringly, listed as a particular role of central government.

Technological forms do not develop independently of the social, economic and political spheres; cannot be invoked as external agents; and do not themselves bring about predictable social change. Rather, they are intrinsic to a social context including its economics, culture, political processes and history. People will do with the technology what suits them. We believe a transformative role for ICTs is a tall order without attention to government collaboration with businesses and communities.

Most particularly, our communities require significant resources for education (rather than 'training') of those targeted for ICT assistance. Perhaps as we continue to track our participants' stories, they will equip themselves to make better use of their computers, but it is clear that the early connection period has had mixed success. Insufficient resources are available to each school community to give more than minimal support to families who need hands-on and active coaching (such as by trained mentors) to continue to use their PC's with success.

We referred earlier to the need for digital literacy as well as information literacy. By way of example, the Computer Clubhouse concept (Resnick, Rusk \& Cooke, 1998) articulates the need for "technological fluency ... not only knowing how to use technological tools, but also knowing how to construct things of significance with those tools" (p. 2). The clubhouse concept, a worldwide network of community access centres for inner-city youth aiming for participants to "learn to express themselves fluently with new technology" (p. 2) and organised by The Computer Museum in collaboration with the MIT Media Lab, is being imported to New Zealand. Clover Park Middle School is to have a "purpose-built facility...[for] 
children aged 10 to 18 [to] create digital artwork, produce their own music CDs, film, write and edit their own short movies, design websites and even build robots" (Otto, 2004).

So far as in other research, we have seen considerable enthusiasm among our participants for the way email facilitates social networks, at least in the early period of connection. However, we tend to agree that

Human nature doesn't change, but social and technological progress tends to amplify its effects. Simply put, the more ways we have to do what comes naturally, the more we do it. (Bonabeau, 2004).

One of the things that comes most naturally to humans is the desire to communicate; the internet amplifies our ability to do so (Tyler, 2002). Tyler makes the point that research is showing people how to "incorporate the internet into their social 'toolkit' and use it ... to deal with personal and interpersonal issues in their lives" (p. 204).

A predominant agenda in New Zealand is for social transformation so that the country may compete more vigorously in economic terms. If this is to happen, a digital strategy will need to go beyond heightened social networking, easily available even to the non-initiated through email, to more advanced understanding of the digital environment required for entrepreneurial activity among the $37 \%$ of New Zealand households equipped to link to the internet from home, as well as the remainder who are not (Archer, 2004). Anecdotal comment from a community worker we spoke to in connection with this research indicates that many households in the low-income area in which she works (and where many of our research participants live) already have a computer at home, but it is not used.

Further, low-income families who have had a brief taste of the internet become targets for marketers keen to sign them up to still-expensive broadband and more powerful computers, even though economic constraints are practically insurmountable for families such as Participant 15 who remarks "This is the first time I've ever got a computer, and ... I can't afford it - I really can't'. If not for CIH with its free internet, this family would have remained unconnected - and may well revert to this, once the six months of free internet is up.

Neither ubiquity of access nor saturation of communities with broadband is enough. The New Zealand government wishes to raise awareness of how ICTs can be transformative and expresses this in its digital strategy document. Our research into Computers in Homes suggests that this programme has value in providing the most basic ICT access, and it is being used by school communities to attempt to broaden people's world-views. Yet claims for community transformation need to be more rigorously assessed. In particular, the dimensions of such transformation must be more precisely articulated by its proponents: a vision of what a community could be, were it to be enhanced by ICT, would provide a mechanism for moving communities toward positive change.

Is social capital really to be enhanced via access to new technologies, and if so, which claims can be justified and which cannot? Researchers must continue to address such questions through longitudinal community research.

\section{References}

Archer, D. (2004). The digital divide 2004. Retrieved 26 July, 2004, from http://statsnz.resultspage.com/search?p=Q\&ts=custom\&w=Digital+Divide

Ball-Rokeach, S. J., Gibbs, J., Hoyt, E. G., Jung, J. Y., Kim, Y. C., Matei, S., et al. (n.d.). Metamorphosis Project white paper \#1 - The challenge of belonging in the 21 st century: The case of Los Angeles. Retrieved 2 September, 2002, from http://www-scf.usc.edu/ matei/stat/globalization.html

Ball-Rokeach, S., Gibbs, J., Jung, J., Kim, Y., \& Qiu, J. (2002). Metamorphosis Project white paper \#2 The globalisation of everyday life: Visions and reality. Retrieved 2 September, 2002, from www.metamorph.org

Bonabeau, E. (2004). The perils of the imitation age. Harvard Business Review, 82(6), 45-54.

Chomsky, N., Mitchell, P. R., \& Schoeffel, J. (Eds.). (2002). Understanding power. London: Vintage. 
Das, D. (2003, 20-23 August 2003). Computers in homes in New Zealand: Addressing gender and culture issues through ICT. Paper presented at the Global Knowledge Partnership Forum on ICT and Gender, Kuala Lumpur, Malaysia.

Digital Strategy: A Draft New Zealand Digital Strategy for Consultation. (2004). NZ Government Ministries of Economic Development, Health, Research Science and Technology and Education; Department of Labour; The NZ National Library, Te Puni Kokiri, State Services Commission, NZ Trade and Enterprise and Local Government NZ.

Fox, S. F., Quitney-Anderson, J., \& Rainie, L. (January 9, 2005). The future of the Internet. Retrieved 24 January, 2005, from http://www.elon.edu/predictions/2004_experts_survey.pdf

Green, L. (2001). Communication, technology and society. London: Sage Publications.

Hampton, K., \& Wellman, B. (2000). Examining community in the digital neighbourhood: Early results from Canada's wired suburb. In T. Ishida \& K. Isbister (Eds.), Digital cities: Technologies, experiences and future perspectives. Berlin: Springer.

Hampton, K., \& Wellman, B. (2003). Neighboring in Netville: How the Internet supports community and social capital in a wired suburb. Retrieved 22 April, 2004, from http://web.mit.edu/knh/www/downloads/cityncomm12-mp.pdf

Hargittai, E. (2004). Digital inequality: From unequal access to differentiated use. In K. Neckerman (Ed.), Social Inequality (pp. 355-400). New York: Russell Sage Foundation.

Horrigan, J. B., \& Rainie, L. (2002). Getting serious online: Pew Internet and American Life Project. Retrieved 3 March, 2002, from http://www.pewinternet.org/reports/pdfs/PIP

Hughes, J., R., \& Hans, J. (2001). Computers, the Internet and families: A review of the role new technology plays in family life. Journal of Family Issues, 22(6), 778-793. Retrieved October 2002 from http://web18.epnet.com/citation.

Jackson, L. A., von Eye, A., Barbatsis, G., Biocca, F., Fitzgerald, H. E., \& Zhao, Y. (2004). The impact of internet use on the other side of the digital divide. Communications of the ACM, 47(7), 43-47.

Kraut, R., Kiesler, S., Boneva, B., Cummings, J., Helgeson, V., \& Crawford, A. (2002). Internet paradox revisited. Journal of Social Issues, 58(1), 49-74.

Kraut, R., Patterson, M., Lundmark, V., Kiesler, S., Mukhopadhyay, T., \& Scherlis, W. (1998). Internet paradox: A social technology that reduces social involvement and psychological well-being. American Psychologist, 53, 1017-1031.

Kwak, N., Skoric, M., Williams, A., \& Poor, N. (2003). The faster, the better? Assessing the impact of broadband internet on knowledge and participation. Paper presented at the Association of Internet Researchers 4th Annual Conference: Broadening the Band, Toronto, Canada.

Lasen, A. (n.d.). The social shaping of fixed and mobile networks: A historical comparison. Retrieved 2 August, 2004, from http://www.surrey.ac.uk/dwrc/papers/HistComp.pdf

Lebo, H. (2004). The digital future report: Surveying the digital future, year four-ten years, ten trends. Retrieved 6 October, 2004, from www.digitalcenter.org

Li, S. C. S. (2004). Examining the factors that influence the intentions to adopt internet shopping and cable television shopping in Taiwan. New Media \& Society, 6(2), 173-193.

Luyt, B. (2004, 19 August 2004). Who benefits from the digital divide? First Monday, 8(9). Retrieved 19 August 2004 from http:www.firstmonday.org/issues/issue9_8/luyt/index.html.

Martinez, F. D. (2003). Diffusion, saturation, and the digital divide. Retrieved 10 August, 2004, from www.unm.edu/ quantum/quantum_2003/diffusion.html

Meegan, R., \& Mitchell, A. (2001). 'It's not community round here, it's neighbourhood': Neighbourhood change and cohesion in urban regeneration policies. Urban Studies, 38(12), 2167-2194. 
Naisbitt, J. (2001). High tech-high touch: Technology and our accelerated search for meaning. London: Nicholas Brealey Publishing.

Novak, T. P., \& Hoffman, D. L. (1998). Bridging the digital divide: The impact of race on computer access and Internet use. Retrieved 3 June, 2004, from http://elab.vanderbilt.edu/research/papers/html/manuscripts/race/science.html

Otto, M. (2004). Clover Park goes to Silicon Valley. Retrieved 24 August, 2004, from http:www.stuff.co.nz/stuff/print/

Pigg, K. E., \& Crank, L. D. (2004). Building community social capital: The potential and promise of information and communications technologies. The Journal of Community Informatics, 1(1). Retrieved 27 October from http://ci-journal.net/viewarticle.php?id=15\&layout=html.

Prensky, M. (2001, 25 January 2005). Digital natives, Digital immigrants. On the Horizon, 9(5). Retrieved 25 January 2005 from http://www.marcprensky.com/writing/Prensky\%20\%20Digital $\% 20$ Natives, \%20Digital\%20Immigrants\%20-\%20Part1.pdf.

Putnam, R. D. (1995a). Bowling alone: America's declining social capital. Journal of Democracy, 6(1), 6578.

Putnam, R. D. (1995b). Tuning in, tuning out: The strange disappearance of social capital in America. PS, Political Science and Politics, 28(4), 664-679.

Putnam, R. D. (1996, 19 March 2004). The strange disappearance of civic America. The American Prospect, 7(24). Retrieved 19 March 2004 from http://www.prospect.org/print/V7/24/putnamr.html.

Putnam, R. D. (2000). Bowling Alone: The collapse and revival of American community. New York: Simon \& Schuster.

Quan Haase, A., Wellman, B., Witte, J., \& Hampton, K. (2002). Capitalizing on the Internet: Social contact, civic engagement, and sense of community. In B. Wellman \& C. Haythornthwaite (Eds.), The Internet and everyday life. Oxford, UK: Blackwell.

Rainie, L., \& Packel, D. (2001, 18 February). More online, doing more. Retrieved November, 2002, from http://www.pewinternet.org/

Rampersad, T. (2004). Who benefits from the digital divide? Retrieved 15 August, 2004, from digitaldivide@milhouse.edc.org http://mailman.edc.org/mailman/listinfo/digitaldivide

Resnick, M., Rusk, N., \& Cooke, S. (1998). The Computer Clubhouse:Technological fluency in the inner city. In D. Schon, B. Sanyal \& W. Mitchell (Eds.), High technology and low-income communities: MIT Press.

Rheingold, H. (1993) The virtual community: Homesteading on the electronic frontier. Reading, MA: Addison-Wesley Publishing Company.

Rogers, E. M. (1995). Diffusion of innovations (5th ed.). New York: Free Press.

Shah, D., Kwak, N., \& Holbert, R. (2001). "Connecting" and "disconnecting" with civic patterns of Internet use and the production of social capital. Political Communication, 18, 141-162.

Shepheard, N. (2004). Textual intercourse. North and South, (August), 50-56.

Stone, W. (2001). Measuring social capital: Towards a theoretically informed measurement framework for researching social capital in family and community life. Melbourne: Australian Institute of Family Studies.

Strauss, A., \& Corbin, J. (1998). Basics of qualitative research (2nd ed.). Thousand Oaks, California: Sage.

Tyler, T. R. (2002). Is the internet changing social life? It seems the more things change, the more they stay the same. Journal of Social Issues, 58(1), 195-205. 
Wellman, B., \& Gulia, M. (1999). "Net-surfers don't ride alone": Virtual communities as communities. In B. Wellman (Ed.), Networks in the global village: Life in contemporary communities. USA: Perseus Books.

Williams, J., Sligo, F., \& Wallace, C. (2004). What a difference IT makes? The Internet in the everyday lives of new user families. Paper presented at the "Making a Difference" annual conference of the Australian and New Zealand Communication Association (ANZCA), University of Sydney.

Winter, I. (2000a). Social capital and public policy in Australia. Melbourne: Australian Institute of Family Studies.

Winter, I. (2000b). Towards a theorised understanding of family life and social capital. Melbourne: Australian Institute of Family Studies.

i "Community" is here associated with a feeling of belonging in a geographical neighbourhood, meaning "place-based community" (Meegan \& Mitchell, 2001, p. 2167) rather than "virtual communities" as first popularised by Howard Rheingold (1993). Therefore we research community as neighbourhoods connected to a particular social context (the low socioeconomic urban primary school). However, we are also interested too in the broader, non-geographical networks that cohere to form other dimensions of community for individuals, households and neighbourhoods.

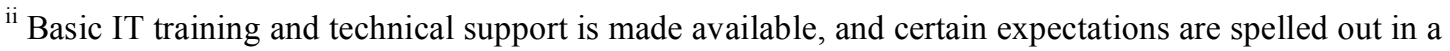
family agreement such as, parents are to: give children up to one hour of supervised internet time per day, look after the computer, and train someone else to use it.

iii Of Pacific Island origin.

iv Our ICI is based on one created for the Metamorphosis study in Los Angeles (Ball-Rokeach, et al., n.d.), which featured eleven survey items, standardised to a 12-point scale and averaged for a single index.

v For within-sample purposes a rating above 7 (out of 12) indicates a high level of internet connectedness, similar to the Metamorphosis study, and a rating of under 5 suggests a 'low connector'.

${ }^{\mathrm{vi}}$ It may be relevant to note here that in the Pew Internet and American Life Project series of studies "a majority of women in the group... tend to email more often than men" (Horrigan \& Rainie, 2002). This is also true of the present study, which inevitably focuses on at-home mothers. The gender profile of our sample is 20: 6, women to men.

vii By percentage of people who report online weekly time with these activities: email and instant messaging top the rankings, with $90.4 \%$ of people spending time on these.

viii This finding may be related to the well-known "Internet Paradox" study (Kraut, et al., 1998), in which in the early months, new users experienced increased depression and isolation; however follow-up work with the same participants found that this was a short-term effect (Kraut, et al., 2002).

ix Marae is a Maori (New Zealand indigenous) word that roughly translates as the sacred place of belonging where a tribal/kinship community meets for important occasions, discussions and rites of passage. It is a formal place of welcome, debate, discussion, and includes traditional buildings and a large area of open ground for welcome and ceremony.

${ }^{x}$ These factors have led to families giving up their involvement in the CIH programme; such instances lend weight to the view that "the binary division of the population between 'online' and 'offline' is misleading" (Hargittai, 2004). Increasingly present is the view that "the type of connection is more important than other digital divide demographics such as education, race or gender" and a refinement of the digital divide is required on the basis of many criteria, not least of which is a differentiation between use of dial-up and use of broadband (Hargittai, 2004; Kwak, Skoric, Williams \& Poor, 2003). Hampton and Wellman's (2003) Netville study of a wired suburb in Toronto found that "always on" high speed 
internet enhances contact with one's neighbours. High speed or broadband increasingly appears likely to be a prerequisite to positive internet experiences. 